\title{
USING PICTURES IN THE ENGLISH AS A FOREIGN LANGUAGE (EFL) CLASSROOMS: EXPLORING ITS POTENTIAL CONTRIBUTION FOR DEVELOPING STUDENTS' WRITING SKILL
}

\author{
Hossein Navidinia*, Amir Raies Ozhan and Armin Younesi \\ Department of English Language, University of Birjand, \\ P.O. Box 615/97175, Birjand, Iran \\ *Corresponding author: navidinia@birjand.ac.ir
}

Published date: 31 March 2019

To cite this article: Navidinia, H., Ozhan, A. R., \& Younesi, A. (2018). Using pictures in the english as a foreign language (EFL) classroom: Exploring its potential contribution for developing students' writing skill. Asia Pacific Journal of Educators and Educations, 33, 1-17. https://doi.org/10.21315/apjee2018.33.1

To link to this article: https://doi.org/10.21315/apjee2018.33.1

\begin{abstract}
With the spread of technology and internet across the world, written communication has received more momentum, and therefore, due attention should be paid to developing English as a Foreign Language (EFL) students' writing skill. The present study tries to examine the potential contribution of using pictures for developing EFL students' writing. For so doing, 34 Iranian EFL learners were selected and randomly divided into two groups, namely control group and experimental group. Before the experiment, both groups answered a writing task as the pre-test. Then, in the experimental group, pictures were used for teaching writing. Thus, when students were asked to write about a topic in the classroom, they were shown some related pictures about that topic. However, in the control group, no picture was used. After 16 sessions of instruction, the same writing task was administered as the post-test in order to measure the effect of using pictures on students' writing development. Then, the performance of the two groups in the pre-test and post-test was compared using ANCOVA. The results indicated that the experimental group could write more words, had less grammatical errors, and used more cohesive devices compared to the control one in the post-test. These findings substantiated the positive effect of using pictures in teaching EFL writing.
\end{abstract}

Keywords: pictures, writing skill, EFL students, language classrooms, language teaching 


\section{INTRODUCTION}

Due to the vast spread of internet and technology in this globalised world, language learners have more opportunities to write for personal and academic purposes. According to Godwin-Jones (2008), social networking websites have provided new chances for personal writing, and language teachers should help learners "to find means to link informal and recreational writing with formal and academic writing" (p. 7). Furthermore, students are asked to write for different purposes in educational contexts and having low proficiency in this skill can negatively influence their success and achievements.

In spite of its significance, previous studies indicated that it is difficult for students to learn writing skill (Ahour \& Mukundan, 2008; Baroudy, 2008; Elbow, 2000; Jun, 2008; Persky, Daane, \& Jin, 2003; Saddler, 2012; Sadiyah, 2011; Salmani Nodoushan, \& Khakbaz, 2011). This difficulty stems from a large number of external and internal factors affecting EFL writing (Anderson, Vanderhoff, \& Donovick, 2013; Chalak \& Norouzi, 2013; Cumming, 2001; Cutler \& Graham, 2008; Hekmati, Ghahremani Ghajar, \& Navidinia, 2018; Ghafar Samar, Navidinia, \& Mehrani, 2010; Nilforooshan \& Afghari, 2007). It is believed that successful writing requires not only foreign language proficiency, but also cross-cultural and discourse knowledge (Xing, Wang, \& Spencer, 2008).

Considering the importance of writing skill, and the difficulties involved in its teaching and learning, many researchers have emphasised the use of techniques and strategies for teaching and practicing this skill (Arndt, 1987; Beare, 2000; Luchini \& Roldán, 2007; Mylan, 2008; Raimes, 1985; Rezaee \& Oladi, 2008; Smedt \& Van Keer, 2014; Victori, 1995).

One of the potential assets that can be used in order to facilitate the procedure of teaching and learning this skill is using visual aids in the classroom. However, despite the previous studies which have been done on the effect of using visual cues and pictures on students' writing performance, no study could be found to address its influence on EFL students' writing length, accuracy, and the use of cohesive devices. Therefore, considering the paucity of studies in this regard and the difficulty and importance of writing skill for EFL students, the present study tries to examine if using pictures in the writing classes can facilitate EFL students' learning of writing skill. More specifically, the study tries to examine the effectiveness of using pictures in the writing classes on students' writing accuracy, length, and the use of cohesive devices. Accordingly, the following questions guide this study: 
1. To what extent can using pictures affect the length of students' writing?

2. To what extent can using pictures affect students' writing accuracy?

3. To what extent can using pictures affect the use of cohesive devices by the students?

\section{LITERATURE REVIEW}

\section{Visual Literacy}

Different scholars have tried to define visual literacy. According to Wileman (1993), visual literacy is "the ability to read, interpret, and understand information presented in pictorial or graphic images" (p. 114). In a similar definition, Heinich, Molenda, Russell and Smaldino (1999) defined this concept as "the learned ability to interpret visual messages accurately and to create such messages" (p. 64). According to Horton (1983), visual literacy is "the ability to understand (read) and use (write) images and to think and learn in terms of images i.e. to think visually" (p. 99). In a more comprehensive and broad conceptualisation, Debes (1969) maintains that visual literacy:

refers to a group of vision-competencies a human being can develop by seeing and at the same time having and integrating other sensory experiences. The development of these competencies is fundamental to normal human learning. When developed, they enable a visually literate person to discriminate and interpret the visible actions, objects, symbols, natural or man-made, that he encounters in his environment. Through the creative use of these competencies, he is able to communicate with others. Through the appreciative use of these competencies, he is able to comprehend and enjoy the masterworks of visual communication (p. 27).

Visual literacy have gained more importance in teaching and learning due to worldwide spread of technology. According to Turbayne (1970), "the visual world is a script we all have to learn" (p. 19). Aristotle even stated that, "without image, thinking is impossible" (as cited in Benson, 1997, p. 141). Furthermore, it is believed that "five of the seven ways in which we form the world are lodged in some form of imagery: spatial, auditory, kinesthetic, emotional, and enactive", and using images in the classroom help students to learn in multiple ways not just in the linguistic mode (Fleckenstein, 2002a, p. 22). Therefore, according to 
Fleckenstein (2002b) "despite this linguistic orientation in our pedagogy and our theories of meaning, we are gradually coming to a renewed acknowledgment of the importance of imagery in our knowing of and being in the world" (p. xiv).

Moreover, Stokes (2002) reviewed a number of studies about the using of visual aids in teaching and learning, and maintained that "using visuals in teaching results in a greater degree of learning" (p. 10). Similarly, D'Angelo (1979) maintains that "wordless books can be used to encourage the development of writing skills, not only with young children who are beginning writers, but also with older students who already possess some skill in writing" (p. 813). Other researchers have also emphasised the importance of using pictures and other visual cues as aids to enrich the learning experience and facilitate learning (Baca, 1990; Bearne \& Wolstencroft, 2007; Brown, Lewis, \& Halcleroad, 1983; Demir, 2017; Elbow, 2000; Harmer, 1988, 2004; Heaton, 2000; Hobson, 2002; Smith, 2002; Walter, 2004; Werner, 2012; Wright, 1989).

\section{Previous Related Studies}

Previous studies have tried to examine if the integration of visual aids can help EFL learners improve their writing skill more effectively. For example, Gutiérrez, Puello and Galvies (2015) examined the efficiency of integrating pictures in developing EFL students' narrative writing. The participants were 20 nine-grader EFL learners. They concluded that using pictures could increase students' narrative skill in English. Also it could increase the students' motivation to practice and improve their narrative writing skill.

Furthermore, Aschawir (2014) investigated the pedagogical benefits of using picture series on five components of students' writing namely, content, organisation, vocabulary, language use, and mechanics. The findings indicated that using pictures can develop students' writing performance. He further maintains that using pictures could help students to concentrate more on the writing task and show more interest for writing. In another study, Wahyuningsih (2011) tries to measure the efficiency of using pictures in students' writing skill. The results indicated that using pictures can enhance students' motivation, and improve their writing performance.

Likewise, Sadiyah (2011) conducted a study to examine the effectiveness of using pictures as an aid to improve high school students' writing performance of descriptive texts. The findings indicated that the use of pictures could improve the students' participation, interaction, and concentration during the learning activity. Also students' writing of descriptive texts was improved by using pictures. 
In addition, Hekmati et al. (2018) tried to examine the effectiveness of integrating films to develop EFL students' writing skill. After 40 hours of instruction, they concluded that by integrating films, students could find a framework for their writings, write about the themes of the films and even criticize them, and know about different genres. They further maintained that, film integration can make the writing class more interesting for the learners and encourage them to be more independent learners.

In another study, Mathew and Alidmat (2013) investigated EFL university students' perception about the use of audio-visual activities in the classroom. Using a questionnaire, they asked students' ideas in this regard in the context of Saudi Arabia. The results indicated that the students acknowledged the beneficial effects of using audio-visual aids in the classroom. The authors further concluded that using audio-visuals in the classrooms can enrich the learning environment and promote students' thinking.

In their quasi-experimental study, Tang and Intai (2017) examined the potential influence of using audio-visual aids in teaching science topics to secondary school students in Malaysia. They divided 30 students into experimental and control groups. For teaching in the experimental group audio-visual aids were used while for the control group the chalk and talk method was applied. The findings indicated that the students in the experimental group who were taught by the use of audiovisual aids outperformed those in the control group. Furthermore, the results indicated that the students in the experiential group believed that integrating visual aids in teaching positively influenced their motivation and interest to learn the subject.

However, no studies in the literature could be found to address the potential influence of visual aids on EFL students' writing length, accuracy, and the use of cohesive devices. Hence, the present study aims to examine this issue in an EFL context. Wiring length (in the allocated time), accuracy and coherence are important features of writing which are considered as standards for scoring applicants' writing performance in many international English language proficiency tests and that was the reason they are considered as the variables in this study.

For example, in IELTS, which is one of the most famous proficiency tests, the four standards of "task response", "coherence and cohesion", "lexical resource" and "grammatical range and accuracy", are considered for scoring applicants" writing performance. "Task Response" refers to the extent that the examinee can address different parts of the task and write the required number of words in the allocated time. "Coherence and Cohesion" is basically the effective use of cohesive devices 
(words or phrases that connect the ideas in the text) while presenting information. "Lexical Resource" is mainly concerned with the range and the precise use of lexical items, and "Grammatical Range and Accuracy" refers to the range and accurate use of grammatical structures.

\section{METHODOLOGY}

\section{Participants}

The participants of this study were 50 pre-intermediate EFL students from both genders (25 male and 25 female) who registered in an English language institute in Birjand City, Iran. The participants' age ranged from 15 to 18 with the mean of 16.5. To gain enough assurance about the homogeneity of the participants, they were asked to answer Preliminary English Test (PET). After the administration of the test, those students whose scores were more than 1 standard deviation higher or lower than the mean were excluded. The remaining homogenous participants (34) were randomly divided into two groups of 17 , namely control and experimental groups.

\section{Procedure}

Participants were exposed to two different types of instructions in this study. For the control group, the researchers provided them a topic for each session and they were asked to write about the topic without any length limitation, but in a fixed period of time (20 minutes). The experimental group was provided with the same topic each session as the control group, but they were given some pictures about that topic from New Oxford Picture Dictionary (Adelson-Goldstein \& Shapiro, 2007) and some other online sources. For example, when the students were asked to write different seasons of the year, some related pictures were shown to the students in the experimental group while the participants in the control group were asked to write without any visual clues. It should be mentioned that general and descriptive topics were selected for writing, so the students did not need any specific background knowledge to write about them.

It is also worth mentioning that both groups were instructed by the same teachers. The treatment lasted for 16 sessions (two sessions per week). A writing task was given to students as pre-test and post-test. The students' performance in the tests were then compared and contrasted to determine the extent that their writing skills were improved. To assess the students' writing skill improvement, we examined the number of words they could write within 20 minutes, the number of grammatical 
errors and mistakes they had, and the number of cohesive devices they used in their wrings. Cohesive devices are words or phrases that connect the ideas in the text. The errors of students' writings were calculated based on Keshavarz's (1999) Model of Error Analysis. In this model, different types of grammatical errors were identified such as: wrong use of tenses, wrong use of parts of speech, wrong use of active and passive voices, wrong use of word order, wrong use of preposition, errors in the use of relative clauses and relative pronoun, double negation, etc.

\section{RESULTS}

The aim of this study was to examine the potential contribution of using pictures for developing EFL students' writing skill. Therefore, we compared students' performance in the pre-test and post-test by using ANCOVA. In this section, the descriptive and inferential statistics of the effect of using pictures on students' writing length, accuracy, and use of cohesive devices were presented separately.

\section{The Effect of Using Pictures on Students' Writing Length}

In both pre-test and post-test, the participants had 20 minutes to write about a writing task. They were asked to write as many words as they could about the topic within this time limitation. Table 1 shows the descriptive statistics of the words that each group wrote in the pre-test and post-test. As indicated in the table, the total number of words written by the students in the pre-test and post-test were 1385 and 1720 , respectively.

Table 1. Descriptive statistics of students' writing length in the pre-test and post-test

\begin{tabular}{lcccccc}
\hline Descriptive statistics & \multicolumn{7}{l}{} \\
\hline & $\mathrm{N}$ & Minimum & Maximum & Sum & Mean & Standard deviation \\
\hline Length-pre-test & 34 & 30.00 & 54.00 & 1385 & 40.7353 & 5.9914 \\
Length-post-test & 34 & 33.00 & 65.00 & 1720 & 50.5882 & 6.96797 \\
\hline
\end{tabular}

Then, in order to examine if using pictures significantly influenced the performance of the experimental group in the post-test, ANCOVA was used. However, in order to use this test, certain assumptions such as equality of variances, normality of the data, and the homogeneity of regression slopes have to be met. As indicated in Tables 2, 3, and 4, these assumptions were met as the significance levels are .921 for equality of variances, .978 for normality, and .298 for homogeneity of regression slopes which are all above .05 . 


\section{Hossein Navidinia et al.}

Table 2. Levene's test of equality variances

\begin{tabular}{cccc}
\hline \multicolumn{4}{l}{ Dependent variable: Length-post-test } \\
\hline$F$ & $\mathrm{df1}$ & $\mathrm{df} 2$ & Sig. \\
\hline .010 & 1 & 32 & .921 \\
\hline
\end{tabular}

Table 3. Kolmogorov-Smirnov test of normality

\begin{tabular}{lccc}
\hline \multicolumn{2}{l}{ Kolmogorov-Smirnov } & & \\
\hline & Statistic & df & Sig. \\
\hline Length-post-test & .120 & 34 & .978 \\
\hline
\end{tabular}

Table 4. Homogeneity of regression slopes

\begin{tabular}{lccccccc}
\hline Dependent variable: Length-post-test & & & & & \\
\hline Source & $\begin{array}{c}\text { Type III sum } \\
\text { of squares }\end{array}$ & df & Mean square & $F$ & Sig. $\begin{array}{c}\text { Partial eta } \\
\text { squared }\end{array}$ \\
\hline Group * length-pre-test & 20.047 & 1 & 20.047 & 1.124 & .298 & .036 \\
\hline
\end{tabular}

As the assumptions have been met, ANCOVA can be run. As indicated in Table 5, there is a significant difference $[F(1,31)=13.99, P=.001]$ in the performance of the experimental group in the post-test. This shows that using pictures could help the students in the experimental group to write more words compared with the words that students in the control group could write.

Table 5. The results of ANCOVA for the students' writing length

\begin{tabular}{lrrrrrc}
\hline Dependent variable: Length-post-test & & & & & \\
\hline Source & $\begin{array}{c}\text { Type III sum } \\
\text { of squares }\end{array}$ & df & $\begin{array}{c}\text { Mean } \\
\text { square }\end{array}$ & $F$ & Sig. & $\begin{array}{c}\text { Partial eta } \\
\text { squared }\end{array}$ \\
\hline Corrected model & 1047.044 & 2 & 523.522 & 29.232 & .000 & .653 \\
Intercept & 222.332 & 1 & 222.332 & 12.414 & .001 & .286 \\
Group & 250.658 & 1 & 250.658 & 13.996 & .001 & .311 \\
Length-pre-test & 764.573 & 1 & 764.573 & 42.691 & .000 & .579 \\
Error & 555.192 & 31 & 17.909 & & & \\
Total & 88614.000 & 34 & & & & \\
Corrected total & 1602.235 & 33 & & & & \\
\hline
\end{tabular}




\section{The Effect of Using Pictures on Writing Accuracy}

At the next step, the influence of using pictures on students' writing accuracy was examined. Table 6 shows the grammatical errors that students had in the pre-test and post-test. As indicated in this Table, the total number of grammatical errors committed by the students in the pre-test and post-test were 145 and 82 , respectively.

Table 6. Descriptive statistics of grammatical errors in the pre-test and post-test

\begin{tabular}{|c|c|c|c|c|c|c|}
\hline \multicolumn{7}{|l|}{ Descriptive statistics } \\
\hline & $N$ & Minimum & Maximum & Sum & Mean & $\begin{array}{l}\text { Standard } \\
\text { deviation }\end{array}$ \\
\hline Grammar-pre-test & 34 & 1.00 & 8.00 & 145.00 & 4.2647 & 1.69328 \\
\hline Grammar-post-test & 34 & .00 & 6.00 & 82.00 & 2.4118 & 1.30541 \\
\hline
\end{tabular}

As indicated in Tables 7, 8, and 9, the assumption of ANCOVA were met as the significance level of the equality of variance is .08 , and those of normality of the data, and the homogeneity of regression slopes were .18 , and .92 which are all more than .05 .

Table 7. Levene's test of equality of variances

\begin{tabular}{lccc}
\hline \multicolumn{4}{l}{ Dependent variable: Grammar-post-test } \\
\hline$F$ & df1 & df2 & Sig. \\
\hline 3.269 & 1 & 32 & .080 \\
\hline
\end{tabular}

Table 8. Kolmogorov-Smirnov test of normality

\begin{tabular}{lccc}
\hline Kolmogorov-Smirnov & & & \\
\hline & Statistic & df & Sig. \\
\hline Grammar-post-test & .127 & 34 & .184 \\
\hline
\end{tabular}

Table 9. Homogeneity of regression slopes

\begin{tabular}{lcccccc}
\hline Dependent variable: Grammar-post-test & $\begin{array}{c}\text { Type III sum } \\
\text { of squares }\end{array}$ & df & $\begin{array}{c}\text { Mean } \\
\text { square }\end{array}$ & $F$ & Sig. & $\begin{array}{c}\text { Partial eta } \\
\text { squared }\end{array}$ \\
\hline Source & .013 & 1 & .013 & .010 & .921 & .000 \\
\hline
\end{tabular}


As shown in Table 10, there is a significant difference $[F(1,31)=8.43, P=.007]$ in the performance of the experimental group in the post-test which means that using pictures helped the students reduce their grammatical errors.

Table 10. The results of ANCOVA for the grammatical accuracy

\begin{tabular}{lccrcrc}
\hline Dependent variable: Grammar-post-test & & & & & \\
\hline Source & $\begin{array}{c}\text { Type III sum } \\
\text { of squares }\end{array}$ & df & $\begin{array}{c}\text { Mean } \\
\text { square }\end{array}$ & $F$ & Sig. & $\begin{array}{c}\text { Partial eta } \\
\text { squared }\end{array}$ \\
\hline Corrected model & 16.155 & 2 & 8.078 & 6.248 & .005 & .287 \\
Intercept & 7.329 & 1 & 7.329 & 5.668 & .024 & .155 \\
Group & 10.902 & 1 & 10.902 & 8.432 & .007 & .214 \\
Grammar-pre-test & 6.626 & 1 & 6.626 & 5.125 & .031 & .142 \\
Error & 40.080 & 31 & 1.293 & & & \\
Total & 254.000 & 34 & & & & \\
Corrected total & 56.235 & 33 & & & & \\
\hline
\end{tabular}

\section{The Effect of Using Pictures on Students' Use of Cohesive Devices}

Finally, the effect of using picture on students' use of cohesive devices were examined. Table 11 shows the descriptive statistics of the cohesive devices that each group used in the pre-test and post-test. As shown in the Table, the total number of cohesive devices used by the participants in the pre-test and post-test were 55 and 120 , respectively.

Table 11. Descriptive statistics of cohesive devices in the pre-test and post-test

\begin{tabular}{lcccrrc}
\hline Descriptive statistics & \multicolumn{1}{c}{ N } & Minimum & Maximum & Sum & Mean & Std. deviation \\
\hline Cohesive devices-post-test & 34 & 1.00 & 6.00 & 120.00 & 3.5294 & 1.35368 \\
Cohesive devices-pre-test & 34 & .00 & 3.00 & 55.00 & 1.6176 & .77907 \\
\hline
\end{tabular}

The assumption of ANCOVA which are equality of variances, normality of the data, and the homogeneity of regression slopes were examined in Tables, 12, 13, and 14. As indicated in the Tables, these assumptions were met as the significance levels are $.24, .20$, and .57 for the three assumptions respectively which are all above .05 . 
Table 12. Levene's test of equality of error variances

\begin{tabular}{lccc}
\hline \multicolumn{4}{l}{ Dependent variable: Lexical-post-test } \\
\hline $\mathrm{F}$ & $\mathrm{df1}$ & $\mathrm{df} 2$ & Sig. \\
\hline 1.427 & 1 & 32 & .241 \\
\hline
\end{tabular}

Table 13. Kolmogorov-Smirnov test of normality

\begin{tabular}{llll}
\hline Kolmogorov-Smirnov & & & \\
\hline & Statistic & df & Sig. \\
\hline Cohesive devices-post-test & .107 & 34 & .200 \\
\hline
\end{tabular}

Table 14. Homogeneity of regression slopes

\begin{tabular}{lccccccc}
\hline Dependent variable: Cohesive devices-post-test & & & & & \\
\hline Source & $\begin{array}{c}\text { Type III sum } \\
\text { of squares }\end{array}$ & df & $\begin{array}{c}\text { Mean } \\
\text { square }\end{array}$ & $F$ & Sig. & $\begin{array}{c}\text { Partial eta } \\
\text { squared }\end{array}$ \\
\hline Group * cohesive devices pre-test & .284 & 1 & .284 & .323 & .574 & .011 \\
\hline
\end{tabular}

As indicated in Table 15, the results of ANCOVA shows a significant difference $[F(1,31)=18.60, P=.000]$ in the performance of the experimental group in the post-test in the use of cohesive devices. This shows that using picture could help the students in the experimental group to write more cohesive devices to connect their ideas and sentences.

Table 15. The results of ANCOVA for the use of cohesive devices

\begin{tabular}{lcccccc}
\hline Dependent variable: Cohesive devices-post-test & & & & & \\
\hline Source & $\begin{array}{c}\text { Type III sum } \\
\text { of squares }\end{array}$ & df & $\begin{array}{c}\text { Mean } \\
\text { square }\end{array}$ & $F$ & Sig. & $\begin{array}{c}\text { Partial eta } \\
\text { squared }\end{array}$ \\
\hline Corrected model & 33.805 & 2 & 16.902 & 19.649 & .000 & .559 \\
Intercept & 29.148 & 1 & 29.148 & 33.886 & .000 & .522 \\
Group & 16.004 & 1 & 16.004 & 18.605 & .000 & .375 \\
Cohesive devices-pre-test & 13.922 & 1 & 13.922 & 16.185 & .000 & .343 \\
Error & 26.666 & 31 & .860 & & & \\
Total & 484.000 & 34 & & & & \\
Corrected total & 60.471 & 33 & & & & \\
\hline
\end{tabular}




\section{DISCUSSION AND CONCLUSION}

The purpose of this study was to examine the effects of using pictures on EFL students' writing performance. After 16 sessions of instruction to two homogenous groups of learners with two approaches, it was found that students learning writing skills with pictures could write more words within the allocated time (20 minutes), used more cohesive devices, and had less grammatical errors compared to the group learning writing without the use of pictures.

The findings of this study are in line with the results of some previous studies conducted in this area (Aschawir, 2014; Gutiérrez et al., 2015; Heaton, 2000; Sadiyah, 2011; Wahyuningsih, 2011), all indicating the positive influence of using pictures and visual cues in improving language learners' writing skill.

According to Aschawir (2014), using pictures while teaching have many advantages such as making the input more realistic and live, helping the learners to concentrate more on the task, and making the class more interesting by forming a link between the classroom tasks and the outside world. Similarly, Gutiérrez et al. (2015) maintain that using picture can improve students' communicative silks and partially compensate for the paucity of input and resources in the language classrooms.

Likewise, the findings of Sadiyah's (2011) study indicated that the integration of visual cues while teaching writing can develop students' competencies for writing descriptive texts, improve learners' interest and attitude towards the learning process, enhance students' enthusiasm to participate in the class activities, increase interaction among the students, and facilitate teacher-students interaction in the classroom.

As the results of this study indicated, there was a significant difference between the control and experimental groups' performance in the post-tests, meaning that the students in the experimental group in which pictures were used for teaching could write longer texts with more cohesive devices and less grammatical errors compared with the performance of the students in the control group. According to Hyland (2003), using visual cues such as photos, pictures, cartoons, and the like can support learning the writing skill by providing schemata for the learners to write. Therefore, it can help students to plan their writing more efficiently, and this may be one reason that the students in the experimental group in this study could write more words and use more cohesive devices. 
Furthermore, according to Bearne and Wolstencroft (2007), the spread of technology has changed writing significantly. As they put it in "everyday printbased communication like newspapers, information leaflets or advertising, words are now almost accompanied by photographs, diagrams or drawing" and a large number of "texts are now multimodal, combining words with moving images, sound, colour, and a range pf photographic, drawn or digitally created visuals" (p. 1). Similarly, Strokes (2002) maintains that "technology, particularly the graphical user interface of the World Wide Web, requires skills for reading and writing visually in order to derive meaning from what is being communicated" (p. 13). Accordingly, considering the new development, not only having visual literacy is needed for all students, but also integrating visual cues in teaching can help the today's students to learn the language more effectively. This is in line with the famous adage "one picture is worth a thousand words".

In line with a number of other studies conducted before (Aschawir, 2014; Gutiérrez et al., 2015; Heaton, 2000; Sadiyah, 2011; Stokes, 2002; Wahyuningsih, 2011), the results of this study further substantiated the positive effect of using visuals in teaching and learning. Therefore, it is suggested that the educational institutions encourage teachers to use visuals as teaching aids in the classroom. Besides, as for the effective use of visuals in the classrooms teachers should have enough knowledge and expertise (Gangwer, 2009; Stokes, 2002), it is necessary that preservice teacher education and in-service professional development programs pay enough attention to this issue.

This present study tried to examine the potential effect of using pictures for developing EFL students' writing skill. The findings substantiated the positive effects of using pictures on EFL students' writing. However, this study had some limitations. Firstly, the participants were not selected randomly from a large population, as they were 50 pre-intermediate students who registered in the language institute and among them 34 were selected based on their performance in the language proficiency test. Also, although the number of the sessions held during the term was 16 , the number of students in each group was 17 that can prevent us from generalising the findings. Therefore, considering the importance of learning EFL writing and the difficulties involved in its learning, and the greater momentum of using multimedia devices in educational settings (Hekmati et al., 2018; Navidinia, Zare Bidaki, \& Hekmati, 2016), it is hoped that more researchers continue this line of research and examine the potential effects of using other audio-visual devices such as cartoons, films, TV, and the like on EFL students' writing development. The potential effect of using pictures in teaching different genres of writing is another area that should be addressed in the future research. 


\section{ACKNOWLEDGEMENTS}

The authors are thankful to the participants of this study because without their cooperation, this study would not have been possible.

\section{REFERENCES}

Adelson-Goldstein, J., \& Shapiro, N. (2007). Oxford picture dictionary (2nd ed.). New York, NY: Oxford University Press.

Ahour, T., \& Mukundan, T. (2008). Analytic assessment of writing: Diagnosing areas of strength and weakness in the writing of TESL undergraduate students. Iranian Journal of Language Studies, 3(2), 195-208.

Anderson, C. E., Vanderhoff, M. A., \& Donovick, J. P. (2013). A manifestation of the bilingual disadvantage in college-level writing. International Journal of Language Studies, 7(1), 139-150.

Arndt, V. (1987). Six writers in search of texts: A protocol-based study of L1 and L2 writing. ELT Journal, 41(4), 257-267. https://doi.org/10.1093/elt/41.4.257

Aschawir, A. (2014). Using series pictures to develop the students' ideas in English narrative writing. Scholarly Journal of Education, 3(7), 88-95.

Baca, J. C. (1990). Identification by consensus of theoretical constructs of visual literacy: A delphi study. Unpublished doctoral dissertation, East Texas State University.

Baroudy, I. (2008). The implementation of process writing: Writing-teacher roles. Iranian Journal of Language Studies, 2(1), 1-18.

Beare, S. (2000). Differences in content generating and planning processes of adult L1 and L2 proficient writers. Unpublished $\mathrm{PhD}$ dissertation, University of Ottawa.

Bearne, E., \& Wolstencroft, H. (2007). Visual approaches to teaching writing. London: Sage Publication.

Benson, P. J. (1997). Problems in picturing text: A study of visual/verbal problem solving. Technical Communication Quarterly, 6(2), 141-160. https://doi.org/10.1207/ s15427625tcq0602_2

Brown, J., Lewis R. B., \& Harcleroad, F. F. (1983). Audio visual instruction. New York: McGraw Hill Book Inc.

Chalak, A., \& Norouzi, Z. (2013). Rhetorical moves and verb tense in abstracts: A comparative analysis of American and Iranian academic writing. International Journal of Language Studies, 7(4), 101-110.

Cumming, A. (2001). Learning to write in a second language: Two decades of research. International Journal of English Studies, 1(2), 1-23.

Cutler, L., \& Graham, S. (2008). Primary grade writing instruction: A national survey. Journal of Educational Psychology, 100(4), 907-919. https://doi.org/10.1037/ a0012656

D'Angelo, K. (1979). Wordless picture books: Also for the writer. Journal of Language Arts, 56(7), 813-814. 
Debes, J. (1969). The loom of visual literacy: An overview. Audiovisual Instruction, 14(8), $25-27$.

Demir, U. G. (2017). The effect of pictures and sentence examples on foreign language vocabulary learning. Journal of Foreign Language Education and Technology, 2(1), 24-38.

Elbow, P. (2000). Everyone can write. New York: Oxford University Press.

Fleckenstein K. S. (2002a). Introduction: Teaching vision: The importance of imagery in reading and writing. In K. S. Fleckenstein, L. T. Calendrillo, \& D. A. Worley, (Eds.), Language and image in the reading-writing classroom: Teaching vision (pp. XIII-IVIII). Mahwah, NJ: Routledge.

Fleckenstein K. S. (2002b). Inviting imagery into our classrooms. In K. S. Fleckenstein, L. T. Calendrillo, \& D. A. Worley (Eds.), Language and image in the readingwriting classroom: Teaching vision (pp. 3-26). Mahwah, NJ: Routledge.

Jun, Z. (2008). A comprehensive review of studies on second language writing. $H K B U$ Papers in Applied Language Studies, 12, 89-123.

Gangwer, T. (2009). Visual impact, visual teaching: Using images to strengthen learning (2nd ed.). Thousand Oaks, CA: Corwin Press.

Ghafar Samar, R., Navidinia, H., \& Mehrani, M. (2010). Communication purposes and strategies in email communication: A contrastive analysis between Iranian and American students. International Journal of Language Studies, 4(3), 207-224.

Godwin-Jones, R. (2008). Web-writing 2.0: Enabling, documenting, and assessing writing online. Language Learning \& Technology, 12(2), 7-13.

Gutiérrez, K. G. C., Puello, M. N. \& Galvies L. A. P. (2015). Using pictures series technique to enhance narrative writing among ninth grade students at Institución Educativa Simón Araujo. English Language Teaching, 8(5), 45-71.

Harmer, J. (1988). Teaching and learning grammar. Harlow, UK: Longman Group UK Limited.

Harmer, J. (2004). How to teach writing. New York: Pearson Education Ltd.

Heaton, J. B. (2000). Beginning composition through pictures. Kuala Lumpur, Malaysia: Longman.

Heinich, R., Molenda, M., Russell, J. D., \& Smaldino, S. E. (1999). Instructional media and technologies for learning (6th ed.). Upper Saddle River, NJ: Prentice-Hall.

Hekmati, N., Ghahremani Ghajar, S., \& Navidinia, H. (2018). Movie-generated EFL writing: Discovering the act of writing through visual literacy practices. International Journal of Language Studies, 12(2), 51-64.

Hobson, E. H. (2002). Teaching the language, I/my students see. In K. S. Fleckenstein, L. T. Calendrillo, \& D. A. Worley (Eds.), Language and image in the readingwriting classroom: Teaching vision (pp. 105-118). Mahwah, NJ: Routledge.

Horton, J. (1983). Visual literacy and visual thinking. In L. Burbank, \& D. Pitt (Eds.), Contribution to the study of visual literacy (pp. 92-106). Bloomington, IN: International Visual Literacy Association.

Hyland, K. (2003). Second language writing. New York: Cambridge University Press. https://doi.org/10.1017/CBO9780511667251

Keshavarz, M. H. (1999). Contrastive analysis and error analysis. Tehran: Rahnama Publications. 
Luchini, P. L., \& Roldán, V. (2007). Monitoring the implementation of the reformulation technique in the EFL writing class: A case study in Argentina. Iranian Journal of Language Studies, 1(4), 227-248.

Mathew, N. G., \& Alidmat, A. O. H. (2013). A study of the usefulness of audiovisual aids in EFL classroom: Implications for effective instruction. International Journal of Higher Education, 2(2), 86-92. https://doi.org/10.5430/ijhe.v2n2p86

Mylan, S. A. (2008). Sight and insight: Mental imagery and visual thinking in the composition classroom. In K. S. Fleckenstein, L. T. Calendrillo, \& D. A. Worley (Eds.), Language and image in the reading-writing classroom: Teaching vision (pp. 73-81). Mahwah, NJ: Routledge.

Navidinia, H., Zare Bidaki, M., \& Hekmati, N. (2016). Incorporating e-learning in teaching English language to medical students: Exploring its potential contributions. Medical Journal of the Islamic Republic of Iran (MJIRI), 30(1), 1195-1201.

Nilforooshan, N., \& Afghari, A. (2007). The effect of field dependence-independence as a source of variation in EFL learners' writing performance. Iranian Journal of Language Studies, 1(2), 103-118.

Persky, H. R., Daane, M. C., \& Jin, Y. (2003). The nation's report card: Writing 2002. Washington, DC: National Center for Education Statistics.

Raimes, A. (1985). What unskilled ESL students do as they write: A classroom study of composing. TESOL Quarterly, 19(2), 229-258. https://doi.org/10.2307/3586828

Rezaee A. A., \& Oladi, S. (2008). The effect of blogging on language learners' improvement in social interactions and writing proficiency. Iranian Journal of Language Studies, 2(1), 2008, 73-88.

Saddler, B. (2012). Motivating writers: Theory and interventions. Reading \& Writing Quarterly: Overcoming Learning Difficulties, 28(1), 1-4. https://doi.org/10.1080 /10573569.2012.632727

Sadiyah, H. (2011). Improving students' ability in writing descriptive texts through picture series-aided learning strategies. The English Teacher, 40, 164-182.

Salmani Nodoushan, M. A., \& Khakbaz, N. (2011). Theses 'Discussion' sections: A structural move analysis. International Journal of Language Studies, 5(3), 111132.

Smedt, D. F., \& Van Keer, H. (2014). A research synthesis on effective writing instruction in primary education. Procedia - Social and Behavioral Sciences, 112, 693-701. https://doi.org/10.1016/j.sbspro.2014.01.1219

Smith, R. M. (2002). Technology, symbol, and discourse: Writing within the information overload. In K. S. Fleckenstein, L. T. Calendrillo, \& D. A. Worley, D. A. (Eds.), Language and image in the reading-writing classroom: Teaching vision (pp. 151-161). Mahwah, NJ: Lawrence Erlbaum Associates.

Stokes, S. (2002). Visual literacy in teaching and learning: A literature perspective. Electronic Journal for the Integration of Technology in Education, 1(1), 10-19.

Tang, D. K. H., \& Intai, R. (2017). Effectiveness of audio-visual aids in teaching lower secondary science in a rural secondary school. Asia Pacific Journal of Educators and Education, 32, 91-106. https://doi.org/10.21315/apjee2017.32.7

Victori, M. (1995). EFL writing knowledge and strategies: An interactive study. Unpublished PhD dissertation, Universitat Autonoma de Barcelona. 
Wahyuningsih, A. (2011). Improving students' writing skill through picture media in grade $x$ of office administration 2 of SMK Negeri 1 Temple. Unpublished BA thesis, Yogyakarta State University.

Werner, W. (2012). Reading visual texts. Theory \& Research in Social Education, 30(3), 401-428. https://doi.org/10.1080/00933104.2002.10473203

Wileman, R. E. (1993). Visual communicating. Englewood Cliffs, NJ: Educational Technology Publications.

Walter, T. (2004). Teaching English language learners. New York: Longman.

Wright, A. (1989). Pictures for language learning. New York: Cambridge University Press.

Xing, M., Wang, J., \& Spencer, K. (2008). Raising students' awareness of cross-cultural contrastive rhetoric via an e-learning course. Language Learning \& Technology, 12(2), 71-93. 